\title{
NUTRITIONAL QUALITY OF AWARA MADE FROM FERMENTED BANJARA BEANS AND SOYBEAN
}

\author{
${ }^{* 1}$ Bintu, B. P., ${ }^{1}$ Falmata, A. S., ${ }^{2}$ Maryam, B. K., ${ }^{1}$ Nnenna, R. O., ${ }^{1}$ Hasina, A. L. \& ${ }^{1}$ Modu, S. \\ ${ }^{1}$ Department of Biochemistry, Faculty of Science, University of Maiduguri, Borno State Nigeria. \\ ${ }^{2}$ Department of Biological Sciences, Faculty of Science, University of Maiduguri, Borno State, Nigeria \\ "Corresponding Author Email: bintubukar@yahoo.com Phone: +2348036300063
}

\begin{abstract}
Awara, a Nigerian soft cheese analogue produced from soy milk using crude coagulant of citric acid and alum. Soybean and banjara bean were used in this study and were evaluated for their proximate composition, mineral element content, antinutritional factors, in vitro protein digestibility and vitamin content using standard procedures. Results obtained indicated that fermented banjara bean awara had a protein content of $2.15 \pm 0.01 \%$, and fermented soybean awara had a protein content of $3.75 \pm 0.01 \%$. Fermented banjara beans awara and soybean awara had a fat content of $5.16 \pm 0.01 \%$ and $17.13 \pm 0.01 \%$ respectively. There were significant differences in the mineral element content of both non fermented and fermented banjara bean and soybean awara. Level of antinutritional factors showed that both tannin and phytic acid were absent in fermented soybean awara. The in vitro protein digestibility of non-fermented and fermented banjara bean and soybean awara significantly increases with time. Vitamin A contents of fermented banjara and soybean awara increased when compared to nonfermented banjara and soybean awara, while a decrease was observed in non-fermented banjara and soybean awara as compared to fermented banjara bean and soybean awara. It can be concluded from this study that fermented soybean awara which is free of antinutritional factors is a more suitable source of protein and fat as a local cheese in this part of the world.
\end{abstract}

Keywords: Awara, Non-Fermented, Fermented, Proximate, in vitro Digestibility

LICENSE: This work by Open Journals Nigeria is licensed and published under the Creative Commons Attribution License 4.0 International License, which permits unrestricted use, distribution, and reproduction in any medium, provided this article is duly cited.

COPYRIGHT: The Author(s) completely retain the copyright of this published article.

OPEN ACCESS: The Author(s) approves that this article remains permanently online in the open access (OA) model.

QA: This Article is published in line with "COPE (Committee on Publication Ethics) and PIE (Publication Integrity \& Ethics)". 


\section{INTRODUCTION}

Cheese is essentially milk curd-substance formed from the coagulation of milk by rennet, pressed or moulded into a solid mass (Kosikowski and Mistry,1997). Different cheese types originate from the milks of different dairy animals (LaBarbera, 2012). Cheese contains concentrated milk solids, water, rennet, salt and sometimes bacterial cultures and calcium chloride (Farah and Fischer, 2004). Cheese can also be prepared from non-dairy products such as soybean cheese awara, (Schaeffer, 2012). Soybean cheese awara, is a healthy, rich and less expensive source of nutrient especially for the developing countries (Nazim et al., 2013).

Soybean and banjara bean are important global crops providing oil and protein. In Nigeria, it is near perfect food for most producers and users (Lucas Brader, 2000). It is affordable in the market. In little more than two decades, Nigeria has become Africa's largest producer of both soybean and cowpea. They are considered as a good source of protein, i.e., having all the essential amino acids including methionine and lysine (Nazim et al.,2013). Soybean and banjara bean are amongst the richest and cheapest source of plant protein. It is relatively low in crude in crude fibre and rich source of vitamin and minerals. There is no denying fact that soybean and cowpea products have many health benefits such as problems associated with protein energy malnutrition.

Tofu, also known as awara in Hausa is an important dietary snack thoughtout Asia, is the most important and popular food product from soybean in Eastern and Southern Asian countries and is gaining an increasing popularity in Western countries as well (Ganiyu and Ekperigin, 2007), it was developed some 2000 years ago and has become the world's most popular soy food product. Tofu, known as awara in Hausa, is an unfermented soy product, also known as soybean curd. It is a soft cheese-like food produced by curding fresh hot soy milk with either a salt (calcium chloride or calcium sulphate) or an acid (glucuno-D-lactose). Traditionally, the curdling agent used to make tofu/awara is calcium sulphate. The coagulant produces a soy protein gel, which traps water, soy lipids, and other constituents in the matrix, forming curds. The curds are then generally pressed to remove the excess water and then cut into cubes (Ganiyu and Ekperigin, 2007).

Awara is a cheese analogue made from soybean. It is a product obtained by curdling soy milk from soybean. A coagulant such as vinegar, tamarind fruit extract, lemon juice, alum, or citric acid is used to bring about the curdling of the soy milk. Traditionally, steep water from ogi is also used as a coagulant. These curds are pressed to remove excess water, cut into blocks and fried in deep hot oil (Desronches et al.,2004). Awara is easy to digest and is substituted for meat, cheese and certain dairy products such as yoghurt, in the diets for dairy-sensitive individuals, vegans and elderly (Ganiyu and Ekperigin, 2007). Based on the coagulant type, awara can be a good source of calcium added to its inherent B-complex vitamins, isoflavones, minerals fibre and unsaturated fatty acid content (Ganiyu and Ekperigin, 2007). It has a very low levels of saturated fat and no cholesterol. It acts like sponge and has the miraculous ability to absorb any flavour that is added to it. Tamarind fruit extracts, vinegar, lemon juice, alum and citric acid are the main coagulants used to precipitate or curdle the casein-like protein, making it easy and possible to separate it from the whey-like protein.

The aim of this study was to determine the, the nutritional quality of awara made from fermented banjara bean and soybean. 


\section{MATERIALS AND METHODS}

The materials used were soybeans (glycine max), banjara bean (awara), vinegar, lemon juice, tamarind fruits extracts, alum and citric acid. These materials were purchased from Maiduguri Monday Market, Borno State, and were authenticated by a Botanist from the Department of Biological science, University of Maiduguri.

\section{PRODUCTION OF AWARA}

The Awara was produced in four (4) ways:

$>$ Production of Awara non- fermented banjara bean.

$>$ Production of Awara from fermented banjara bean

$>$ Production of Awara from non-fermented soybean

$>$ Production of Awara from fermented soybean

\section{PRODUCTION OF AWARA FROM NON- FERMENTED BANJARA BEAN}

Preparation of Banjara Bean milk: cowpea was steeped in cold water for 10minutes to soften the seed and the banjara bean was then dehulled. They washed separating the hull from the fine grain. The bean was ground into a paste using hammer mill. Water was added and mixed gradually with the paste to form slurry which was the filtered to extract (Banjara bean milk) using a muslin cloth. The sides of the cloth were held in each hand and moved up and down to roll the pulp back and forth it forms a ball. The cloth was twisted tightly and held over a clean container while pressure was exerted onto it to extract the remaining banjara bean milk. Coagulation of banjara bean milk: Banjara bean milk was boiled for $20-25$ minutes at $100^{\circ} \mathrm{C}$, the coagulant (citric acid) was added to the cowpea milk forming sediment at the bottom of the pot the sediment part was collected washed and diced and fried in deep hot oil (Fukushima, 1981).

\section{PRODUCTION OF AWARA FROM FERMENTED BANJARA BEAN}

Preparation of fermented banjara bean milk: Banjara was soaked in cold water for 72 hours days to ferment it. After the water was discarded, they were washed and drained in clean water. A hammer mill was used to grind the beans into a paste. Water was added and mixed gradually with the paste to form slurry which was the filtered to extract (Banjara milk) using a muslin cloth. The sides of the cloth are held in each hand and moved up and down to roll the pulp back and forth it forms a ball. The cloth was twisted tightly and held over a clean container while pressure was exerted onto it to extract the remaining banjara bean milk. Coagulation of fermented banjara bean milk: Fermented banjara bean milk was heated and boiled for 20-25 minutes. The banjara bean milk forms a sediment at the bottom of the pot. The sediment part was collected washed, diced and fried in deep hot oil (Fukushima,1981).

\section{PRODUCTION OF AWARA FROM NON- FERMENTED SOYBEAN}

Preparation of soymilk: soybean was soaked in cold water over night for 2-3 hours. When the soybean splits open easily, they were ready to be drained. After then the water was discarded, they were washed in clean water. A hammer mill was used to grind the beans into a paste. Water was added and mixed gradually with the paste to form slurry which was filtered to extract (soy milk) using a muslin cloth. The sides of the cloth were held in each hand and moved up and down to roll the pulp back and forth. The cloth is twisted tightly and held over a clean container while pressure was exerted onto it to extract the remaining soymilk. 
Coagulation of soymilk: Soymilk was heated and boiled for $20-25$ minutes at $100^{\circ} \mathrm{C}$. The coagulant (citric acid) was added to the soymilk until a good coagulum was formed. when a large white curd are seed floating in a clear yellow liquid called 'whey', the soymilk was completely curdled and ready to be filtered through a clean muslin cloth into a suitable mould. The curdled soymilk was removed from the pot inside the muslin cloth and pressed until the water content was removed to from a block of Awara. The block obtained was diced and fried in deep hot oil (Fukushima,1981).

\section{PRODUCTION OF AWARA FROM FERMENTED SOYBEAN}

Preparation of fermented soymilk: Soybean was soaked in cold water for about 3 days to ferment it. After the water was discarded, they are washed and drained in clean water. A hammer mill was used to grind the beans into a paste. Water was added and mixed gradually with the paste to form slurry which was filtered to extract (soy milk) using a muslin cloth. The sides of the cloth were held in each hand, moved up and down to roll the pulp back and forth. The cloth was twisted tightly and held over a clean container while pressure was exerted onto it to extract the remaining soymilk. Coagulation of fermented soymilk: Fermented soymilk was heated and boiled for 20-25 minutes. The coagulant (citric acid) was added to the fermented soymilk until a good coagulum was formed. when a large white curd are seed floating in a clear yellow liquid called 'whey', the fermented soymilk was completely curdled and ready to be filtered through a clean muslin cloth into a suitable mould. The curdled soymilk was removed from the pot inside the muslin cloth and pressed until the water content was removed to from a block of Awara. The block obtained was diced and fried in deep hot oil (Fukushima,1981).

\section{Determination of Proximate Composition.}

Proximate analysis (Moisture, Ash, Crude Protein, Crude fat, Crude fiber and Carbohydrate) was determined according to method described by AOAC (2000)

\section{DETERMINATION OF MOISTURE CONTENT}

Two $(2 \mathrm{~g})$ of sample was weighed into a petri dish of known weight and dried to a constant weight at $105^{\circ} \mathrm{C}$ for 5 hours in an oven. The dried sample was cooled in a dessiccator and weighed. The difference in weight of the sample was the moisture content.

$\%$ moisture $=$ loss in weight of drying/initiate weight of the sample $\mathrm{x} 100$

\section{DETERMINATION OF ASH}

A silica dish was cleaned, ignited, cooled (in a desiccator and weighed $\left(\mathrm{W}_{1}\right)$. Test substance (5 grams) labeled $\mathrm{W}_{2}$ was weighed accurately directly into the silica dish. Using a pair of tongs, the weighed samples were placed in a muffle furnace and the temperature was set at $500^{\circ} \mathrm{C}$ until fully turned ash (grey colour of ash). Upon ashing, the dish with the ash was removed from the furnace and kept in a dessicator to cool before weighing $\left(\mathrm{W}_{3}\right)$.

$$
\begin{aligned}
\% \mathrm{Ash}= & \left(\mathrm{W}_{3}-\mathrm{W}_{1}\right) \times 100 \\
& \left(\mathrm{~W}_{2}-\mathrm{W}_{1}\right)
\end{aligned}
$$




\section{DETERMINATION OF PROTEIN (KJEDAHL METHOD)}

\section{DIGESTION}

About $2 \mathrm{~g}$ of the sample was weighed into Kjedahl digestion tubes and $20 \mathrm{ml}$ of sulphuric acid added. The tube was heated in the digestion chamber for $16-18$ hours. $\mathrm{NaOH}$ was added and the volume was made up to $100 \mathrm{ml}$ by distilled water.

\section{DISTILLATION}

Five millilitres (5mls) of Borate were pipetted into a conical flask and 3- 4 bromocresol and methylene indicator was added into the conical flask. Five millilitres of the digested sample were introduced into the distillation flask through the funnel and 15-20 mls of $40 \% \mathrm{NaOH}$ will then be added into the distillation flask. All the inlets were closed.

The conical flask containing the borate and mixed indicators was placed at the extended tube (outlet) of the distilation unit and $50-75 \mathrm{ml}$ of the distillate was collected into the conical flask. This was titrated with the standard $\mathrm{HCl}$.

\section{STANDARDIZATION OF HCL}

Five milliliters $(5 \mathrm{mls})$ of ammonium solution was pipetted and distilled with about $15 \mathrm{ml}$ of $40 \%$ sodium hydroxide solution. The liberated ammonia was collected in a conical flask containing $5 \mathrm{ml}$ of $2 \%$ boric acid and 4 drops of mixed indicator. The ammonia solution was titrated with the standard $\mathrm{HCl}$. The amount of $\mathrm{HCl}$ required for the titration was the acid factor that was used in the calculations of crude protein content.

The percentage protein was calculated using the formula.

$$
\mathrm{A} \times \mathrm{N} \times \mathrm{F} \times 14.007 \times 100
$$

Weight of sample $\mathrm{x}$ Aliquot taken

Where

$\begin{array}{lll}\mathrm{A} & = & \text { Volume of the acid used } \\ \mathrm{N} & = & \text { Molarity of acid } \\ \mathrm{F} & = & \text { Factor } 6.25\end{array}$

\section{DETERMINATION OF CRUDE FAT}

Fat was determined by the soxhlet extraction method. About $3 \mathrm{~g}$ of each sample was weighed into fat extraction thimbles and covered with cotton wool to prevent splashing of the sample during extraction. The extraction units (tecator soxhlet 1046) was set up and fat was extracted using petroleum ether.

$$
\% \text { extractable fat }=\quad \underline{\mathrm{W}}_{3}-\mathrm{W}_{2} \times 100
$$

$$
\mathrm{W}_{1}
$$

Where
$\mathrm{W}_{1}=\quad$ Weight of sample before extraction
$\mathrm{W}_{2}=$ Weight of sample without fat
$\mathrm{W}_{3}=$ Weight of flask with fat 


\section{DETERMINATION OF CARBOHYDRATE}

The carbohydrate (Nitrogen-free extract) content was determined by the difference obtained after the subtraction of total crude protein, fat, ash and crude fibre from the total dry matter.

Percentage of carbohydrate (Nitrogen-free extract)

$$
=100-(\% \text { moisture }+\% \text { protein }+\% \text { ash }+\% \text { fat }+\% \text { crude fibre }) .
$$

\section{TOTAL ENERGY}

The total energy value was calculated according to the method of Mohgoub (1999), using the formula:

Total energy $($ Kcal $/ 100 g)=$

$[(\%$ available carbohydrates $\mathrm{x} 4)+(\%$ protein $\mathrm{x} 4)+(\%$ fat $\mathrm{x} 9)]$

\section{DETERMINATION OF MINERAL ELEMENT}

Atomic Absorption Spectrophotometer (AAS) AA 6800 series Shimazo Corp was used for the determination of Ca, $\mathrm{Cu}, \mathrm{Zn}, \mathrm{Mg}, \mathrm{P}, \mathrm{Na}, \mathrm{Mn}, \mathrm{Fe}, \mathrm{Zn}$ and $\mathrm{k}$. Two grams (2 g) of sample was weighed into a crucible and incinerated at $600^{\circ} \mathrm{C}$ for 2 hours. The ashed sample was transferred into $100 \mathrm{ml}$ volumetric flask and $100 \mathrm{ml}$ of distilled water was added into it and readings taken on the AAS.

\section{DETERMINATION OF ANTINUTRIENT}

Tannin content determination of the non- fermented and fermented banjara bean and soybean awara were determined by the method described by Price and Butler, (1997).0.2g of sample was weight into Erlenmeyer flask, and 10ml of $4 \% \mathrm{Hcl}$ in methanol was pipeted into the flask. The flask was closed with parapilus and shaken for $20 \mathrm{minutes}$ on a wrist action shaker. $1 \mathrm{ml}$ of extract was pipetted and $1 \mathrm{ml}$ of $1 \%$ vanillin and $0.5 \mathrm{ml}$ of concentrated Hcl was added. Five test tubes were labelled I, II, III, IV and V to prepare the standard solutions into the five test tubes, 0.1, 0.3, 0.5, 0.7 and $1.0 \mathrm{ml}$ of phenol reagent was added respectively. The test tube was made up to $1 \mathrm{ml}$ with methanol $(8 \% \mathrm{Hcl}$ in methanol). $1.0 \mathrm{ml}$ of $1 \%$ vanilin and $0.5 \mathrm{ml}$ concentrated $\mathrm{Hcl}$ was added to the tubes and made up to $5.5 \mathrm{ml}$ with $4 \% \mathrm{Hcl}$ in methanol/ blank sample was prepared by using $5 \mathrm{ml}$ of $4 \% \mathrm{Hcl}$ in methanol. The absorbance of the standard solutions, sample extract and blank were read using a spectrophotometer at 500nm 20 minutes after incubation.

Calculation:

$$
\begin{aligned}
& \mathrm{Au} / \mathrm{Cu}=\mathrm{Astd} / \mathrm{Cstd} \\
& \mathrm{Cu}=\mathrm{Au} / \mathrm{Astd} * \mathrm{Cstd}=\mathrm{mg} / \mathrm{g} \\
& \text { Where } \mathrm{Au}=\text { absorbance of unknown } \\
& \mathrm{Cu}=\text { concentration of unknown } \\
& \mathrm{Astd}=\mathrm{absorb} \text { ance of standard } \\
& \mathrm{Cstd}=\text { concentration of standard }
\end{aligned}
$$

\section{DETERMINATION OF PHYTIC ACID}

Phytic acid content of the raw and processed pearl soybean and banjara beans samples were determined according to the method described by Davies and Reid, (1979). One gram of sample was extracted by taking 40ml 0f $0.5 \mathrm{~m}$ nitric acid in a conical flask and shaken at $30^{\circ} \mathrm{c}$ and 80 revolutions per minutes. the sample were filtered and $5 \mathrm{ml}$ of $0.08 \mathrm{M}$ ferric chloride was added and boiled for 20minute and filtered. The free iron remaining in the solution was determined 
calorimetrically by adding $2 \mathrm{ml}$ of $0.005 \mathrm{M}$ ammonium thiocynate and the iron binding capacities of the extract was determined by difference. The results were expressed in terms of Mg Fe bound per gram of sample.

\section{DETERMINATION OF IN VITRO PROTEIN DIGESTIBILITY}

The in vitro protein digestibility of the samples was determined according to the method described by Nills (1979). $1 \mathrm{ml}$ of $11 \%$ trypsin was introduced into three test tube $4 \mathrm{ml}$ of phosphate buffer at $\mathrm{pH} 7.5$ was added into each test tube and $1 \mathrm{ml}$ of $1 \%$ sample was added to all the test tube (labeled as digestibility at Ohour, 1hour and 6hour). The reaction in each test tube was stopped with $5 \mathrm{ml}$ of neutralized formalin at 1 hour and 6hour. The content of the test tube was filtered using filter paper. The filter papers were dried in an oven at $180 . \mathrm{c}$ for $3 \%$ hours. The nitrogen of the undigested sample was determined by kjedahl method.

$\%$ in vitro protein digestibility $=\frac{\mathrm{CP} 1-\mathrm{CP} 2}{\mathrm{CP} 1} \times 100$

Where;

$\mathrm{Cp} 1=$ total protein of unprocessed grain

$\mathrm{Cp} 2=$ total protein after digestion with trypsin

\section{DETERMINATION OF VITAMIN CONTENT}

\section{VITAMIN A ASSAY}

Source: method adopted from USP 2007 volume 1

Standard preparation: dissolve an accurately weighed quantity of USP vitamin A reference standard in n-hexane and dilute quantitatively and stepwise, if necessary, to obtain a solution having a known concentration of about $15 \mathrm{ug}$ $(0.015 \mathrm{mg})$ of retinol acetate per $\mathrm{ml}$

Assay preparation: Transfer about $15 \mathrm{mg}$ of vitamin ester (retinol acetate or retinyl palmitate), accurately weighed to $100 \mathrm{ml}$ volumetric flask, dissolved in and dilute with $\mathrm{n}$-hexane to volume and mix. Pipette $5.0 \mathrm{ml}$ of the solution into a $50 \mathrm{ml}$ volumetric flask, dilute with $\mathrm{n}$-hexane to volume mix and scan at $210 \mathrm{~nm}$.

W.C $=\frac{20}{100} \times \frac{1}{10}=0.02 \mathrm{mg} / \mathrm{ml}$ (modified)

Sample preparation:

Dissolve $1 \mathrm{~g}$ of the sample in $10 \mathrm{ml}$-hexane, sonicate for $30 \mathrm{~min}$, centrifuge at $2500 \mathrm{rpm}$ for $10 \mathrm{~min}$ and collect the supernant in a cuvette and scan in UV spectrophotometer at $210 \mathrm{~nm}$

Using bear lambert's law

$\mathrm{A}=\mathrm{abc}$

Where $\mathrm{A}=$ absorbance

$$
\begin{aligned}
& a=\text { molar absorptivity } \\
& b=\text { path length of cuvette } \\
& c=\text { concentration }
\end{aligned}
$$

Where $\mathrm{ab}=$ constant

$$
\begin{aligned}
& \text { Ab standard }=\mathrm{C} \text { standard } \\
& \mathrm{Ab} \text { sample }=\mathrm{C} \text { sample }
\end{aligned}
$$




\section{VITAMIN C ASSAY - BROMOSUCCINAMIDE}

\section{SAMPLE PREPARATION}

$10 \%$ solutions of the dried sample were made differently, filtered using filter paper method. $5 \mathrm{ml}$ of the filtrate was analyzed for vitamin C (Ascorbic acid).

\section{PROCEDURE}

Weigh $0.2 \mathrm{~g}(200 \mathrm{mg}$ ) Bromosuccinamide in $100 \mathrm{ml}$ of warm water to dissolve (stock solution), measure 10ml from the stock solution and make up to $100 \mathrm{ml}$ of distill water (working solution), dissolve $0.2 \mathrm{~g}$ (200mg) ascorbic acid in 1 liter of $1 \%$ acetic acid $(10 \mathrm{ml}$ of acetic acid in that 1 liter) make up to 1 liter.

\section{STANDARDIZE}

Take $5 \mathrm{ml}$ of standard ascorbic acid and add $1 \mathrm{ml}$ conc. Acetic acid. $5 \mathrm{ml}$ of $4 \% \mathrm{KI}$, add $3 \mathrm{ml}$ of dethyl ether, titrate against Bromosuccinamide until brown coloration shown on the ether layer. Take $5 \mathrm{ml}$ of your sample instead of standard ascorbic acid and add $1 \mathrm{ml}$ of conc. Acetic acid, $5 \mathrm{ml}$ of $4 \% \mathrm{KI}$, add $3 \mathrm{ml}$ of dethyl ether, titrate against Bromosuccinamide until brown color appears on the ether layer.

\section{RESULTS}

\section{PROXIMATE COMPOSITION}

Proximate composition of non-fermented and fermented banjara and soybean awara is shown in Table 1. The moisture, Ash and protein of non-fermented awara are (16.08 \pm 0.02$),(2.10 \pm 0.01)$ and (2.06 \pm 0.03$)$. while fermented awara had (31.35 \pm 0.01$),(4.43 \pm 0.01)$ and $(3.15 \pm 0.01)$. A significant decrease was observed in the fat, carbohydrate and energy value of fermented banjara $(5.16 \pm 0.016),(56.91 \pm 0.01)$, and $(282.88 \pm 0.01)$ when compared to nonfermented banjara (8.72 \pm 0.01$)$, (71.04 \pm 0.03$)$ and $(370.86 \pm 0.09)$. Soybean awara had a significant increase in moisture, Ash, protein and fat of fermented awara $(18.92 \pm 0.01),(6.47 \pm 0.01)(3.75 \pm 0.01)$ and $(17.13 \pm 0.01)$ and nonfermented awara showed moisture, Ash, protein and fat content of (4.95 \pm 0.04$),(2.86 \pm 0.01),(1.59 \pm 0.01)$ and (14.37 \pm 0.02$)$. significant decreases were observed between the carbohydrate and energy levels of non-fermented (76.23 \pm 0.02$),(440.63 \pm 0.09)$ fermented soybean awara $(53.73 \pm 0.01)$ and $(384.09 \pm 0.10)$ respectively.

Table 1: The proximate composition of raw and fermented soybean and banjara awara

\begin{tabular}{lllllll}
\hline Sample & $\begin{array}{l}\text { Moisture } \\
(\boldsymbol{\%})\end{array}$ & $\begin{array}{l}\text { Ash } \\
(\boldsymbol{\%})\end{array}$ & $\begin{array}{l}\text { Protein } \\
(\boldsymbol{\%})\end{array}$ & $\begin{array}{l}\text { Fat } \\
(\boldsymbol{\%})\end{array}$ & $\begin{array}{l}\text { Carbohydrates } \\
(\boldsymbol{\%})\end{array}$ & $\begin{array}{l}\text { Total energy } \\
(\boldsymbol{\%})\end{array}$ \\
\hline NFB & $16.08 \pm 0.2^{\mathrm{a}}$ & $2.10 \pm 0.01^{\mathrm{a}}$ & $2.06 \pm 0.03^{\mathrm{a}}$ & $8.72 \pm 0.01^{\mathrm{a}}$ & $71.04 \pm 0.03^{\mathrm{a}}$ & $370.86 \pm 0.00^{\mathrm{a}}$ \\
& & & & & & \\
FB & $31.35 \pm 0.01^{\mathrm{b}}$ & $4.43 \pm 0.01^{\mathrm{b}}$ & $2.15 \pm 0.01^{\mathrm{b}}$ & $5.16 \pm 0.01^{\mathrm{b}}$ & $56.91 \pm 0.02^{\mathrm{b}}$ & $282.66 \pm 0.00^{\mathrm{b}}$ \\
NFS & $4.95 \pm 0.04^{\mathrm{a}}$ & $2.86 \pm 0.01^{\mathrm{a}}$ & $1.59 \pm 0.01^{\mathrm{a}}$ & $14.37 \pm 0.00^{\mathrm{a}}$ & $76.23 \pm 0.02^{\mathrm{a}}$ & $440.63 \pm 0.09^{\mathrm{a}}$ \\
FS & $18.92 \pm 0.01^{\mathrm{b}}$ & $6.47 \pm 0.01^{\mathrm{b}}$ & $3.75 \pm 0.01^{\mathrm{b}}$ & $17.13 \pm 0.01^{\mathrm{b}}$ & $53.73 \pm 0.01^{\mathrm{b}}$ & $384.09 \pm 0.00^{\mathrm{b}}$ \\
\hline
\end{tabular}

Values are presented in mean \pm SEM,

Mean values with different superscript along the column are statistically different $(\mathrm{p}<0.05)$.

Key:

$\mathrm{NFB}=$ Non-Fermented Banjara FB=Fermented Banjara NFS=Non-Fermented Soybean FS=Fermented Boybean 
THE MINERAL ELEMENT COMPOSITION OF NON-FERMENTED AND FERMENTED BANJARA BEAN AND SOYBEAN $A$ WARA.

Elemental analysis of non-fermented and fermented banjara and soybean awara. Calcium, potassium, zinc, magnesium, sodium and iron content of non-fermented banjara bean awara ranged from (0.36 \pm 0.01$),(10.01 \pm 0.01)$, $(0.38 \pm 0.01),(0.12 \pm 0.03)(59.70 \pm 0.58)(0.22 \pm 0.02)$ and fermented banjara bean awara had $(0.12 \pm 0.01),(7.02 \pm 0.01)$, $(1.06 \pm 0.01),(0.39 \pm 0.01)(124.30 \pm 0.15)$ and $(0.36 \pm 0.02)$ respectively. Non-fermented soybean awara had a calcium, zinc, magnesium and potassium levels of $(0.22 \pm 0.01),(0.31 \pm 0.02),(0.70 \pm 0.01)$ and $(10.02 \pm 0.02)$ which are higher than that of the fermented soybean awara $(0.11 \pm 0.02),(0.21 \pm 0.01),(0.35 \pm 0.01)$ and $(8.11 \pm 0.01)$ low levels were recorded for non-fermented soybean awara in terms of iron and sodium $(0.24 \pm 0.01),(18.50 \pm 0.06)$ when compared to fermented soybean awara which showed higher values of $(0.26 \pm 0.01),(99.60 \pm 0.12)$ respectively.

Table 2: The Mineral Element Composition of Non-Fermented and fermented Banjara Bean and Soybean awara.

\begin{tabular}{lllll}
\hline Nutrient & NFB & FB & NFS & FS \\
\hline Calcium & $0.36 \pm 0.01^{\mathrm{C}}$ & $0.12 \pm 0.01^{\mathrm{a}}$ & $0.22 \pm 0.01^{\mathrm{b}}$ & $0.11 \pm 0.02^{\mathrm{a}}$ \\
Copper & $0.21 \pm 0.02^{\mathrm{a}}$ & $0.12 \pm 0.01^{\mathrm{b}}$ & $0.17 \pm 0.01^{\mathrm{c}}$ & $0.20 \pm 0.01^{\mathrm{a}}$ \\
Zinc & $0.38 \pm 0.01^{\mathrm{d}}$ & $1.06 \pm 0.01^{\mathrm{b}}$ & $0.31 \pm 0.02^{\mathrm{c}}$ & $0.21 \pm 0.01^{\mathrm{a}}$ \\
Magnesium & $0.12 \pm 0.03^{\mathrm{d}}$ & $0.39 \pm 0.01^{\mathrm{b}}$ & $0.70 \pm 0.01^{\mathrm{c}}$ & $0.35 \pm 0.01^{\mathrm{a}}$ \\
Phosphorus & $0.37 \pm 0.01^{\mathrm{d}}$ & $0.11 \pm 0.01^{\mathrm{b}}$ & $0.11 \pm 0.01^{\mathrm{cb}}$ & $0.25 \pm 0.01^{\mathrm{a}}$ \\
Sodium & $59.70 \pm 0.58^{\mathrm{d}}$ & $124.30 \pm 0.15^{\mathrm{b}}$ & $18.50 \pm 0.06^{\mathrm{c}}$ & $99.60 \pm 0.12^{\mathrm{a}}$ \\
Manganese & $0.25 \pm 0.01^{\mathrm{d}}$ & $0.37 \pm 0.02^{\mathrm{b}}$ & $0.22 \pm 0.01^{\mathrm{c}}$ & $0.40 \pm 0.01^{\mathrm{a}}$ \\
Iron & $0.22 \pm 0.02^{\mathrm{d}}$ & $0.36 \pm 0.02^{\mathrm{b}}$ & $0.24 \pm 0.01^{\mathrm{c}}$ & $0.26 \pm 0.01^{\mathrm{a}}$ \\
Potassium & $10.01 \pm 0.01^{\mathrm{dc}}$ & $7.02 \pm 0.01^{\mathrm{b}}$ & $10.02 \pm 0.02^{\mathrm{c}}$ & $8.11 \pm 0.01^{\mathrm{a}}$ \\
\hline
\end{tabular}

Values are presented in mean \pm SEM

Values with different superscript along the column are significantly different $(\mathrm{P}<0.05)$.

Key:

$\mathrm{NFB}=$ Non-Fermented banjara FB=Fermented banjara NFS=Non- Fermented soybean FS=Fermented soybean

THE ANTINUTRITIONAL FACTORS OF NON- FERMENTED AND FERMENTED BANJARA BEAN AND SOYBEAN AWARA.

Table 3: The antinutrition factors of non-fermented and fermented banjara and soybean awara. Both tannin and phytic acid were detected in non-fermented banjara bean awara, however no tannin was present in the fermented banjara bean awara. There was a presence of both tannin and phytic acid in the non-fermented soybean awara while non was detected in fermented soybean awara.

Table 3: Antinutritional Factors of Non- Fermented and Fermented Banjara bean and Soybean Awara.

\begin{tabular}{lcc}
\hline Sample & Tannin & Phytic acids \\
\hline NFB & - & + \\
FB & - & + \\
NFS & + & + \\
FS & - & - \\
\hline
\end{tabular}

\section{Keys}

$\mathrm{NFB}=$ Non-Fermented Banjara FB=Fermented Banjara NFS= Non-Fermented Soybean FS=Fermented Soybean 
Table 4: The In vitro protein digestibility of non-fermented and fermented banjara and soybean awara. At one (1) hour digestibility both non-fermented and fermented banjara soybean awara were significantly the same but a significant increase was observed at six (6) hours digestibility. The in vitro protein digestibility reveals an increase in time from 1 hour to 6 hours in both non-fermented and fermented samples.

Table 4: In vitro Protein Digestibility of Non-Fermented and Fermented Banjara and Soybean Awara

\begin{tabular}{lllll}
\hline Digestibility & \multicolumn{3}{c}{ SAMPLE } \\
& NFB & FB & NFS & FS \\
\hline 1 HOUR (\%) & $9.69 \pm 0.01^{\mathrm{a}}$ & $10.28 \pm 0.01^{\mathrm{a}}$ & $51.54 \pm 0.01^{\mathrm{b}}$ & $52.28 \pm 0.01^{\mathrm{b}}$ \\
6 HOUR (\%) & $8.80 \pm 0.01^{\mathrm{a}}$ & $48.75 \pm 0.01^{\mathrm{b}}$ & $28.05 \pm 0.01^{\mathrm{a}}$ & $58.51 \pm 0.01^{\mathrm{b}}$ \\
\hline
\end{tabular}

Values are mean \pm SEM,

Values with different superscript along the row are significantly $(\mathrm{p}<0.05)$ different.

Keys

NFB $=$ Non-Fermented Banjara FB = Fermented Banjara NFS = Non-Fermented Soybean FS = Fermented Soybean

Table 5: The vitamin A and C of non-fermented and fermented banjara and soybean awara. There was a significant difference in the vitamin A content of non-fermented and fermented banjara bean awara while and increase was observed in the fermented soybean awara. Fermented banjara bean awara had low vitamin $\mathrm{C}(0.53 \pm 0.01)$ while nonfermented banjara bean awara had high vitamin $\mathrm{C}$ value $(0.79 \pm 0.01)$ non-fermented soybean awara had (1.05 \pm 0.01$)$ while fermented soybean awara had values of $(0.79 \pm 0.01)$.

Table 5: Vitamin Content of Non-Fermented and Fermented of Banjara and Soybean Awara.

\begin{tabular}{lllll}
\hline Vitamins $(\boldsymbol{\mu g} / \mathbf{g})$ & \multicolumn{3}{c}{ Sample } \\
& NFB & FB & NFS & FS \\
\hline A & $0.12 \pm 0.01^{\mathrm{a}}$ & $0.13 \pm 0.01^{\mathrm{a}}$ & $0.12 \pm 0.01^{\mathrm{a}}$ & $0.46 \pm 0.01^{\mathrm{b}}$ \\
$\mathrm{C}$ & $0.79 \pm 0.01^{\mathrm{a}}$ & $0.53 \pm 0.01^{\mathrm{b}}$ & $1.05 \pm 0.01^{\mathrm{a}}$ & $0.79 \pm 0.01^{\mathrm{b}}$ \\
\hline
\end{tabular}

Values are mean \pm SEM

Values with different superscript along the row are significantly $(\mathrm{p}<0.05)$ different.

Keys

NFB $=$ Non-Fermented Banjara FB = Fermented Banjara NFS = Non -Fermented Soybean FS = Fermented Soybean

\section{DISSCUSSION}

The high levels observed in fermented banjara bean and soybean awara might be attributed to the processing technique fermentation. Fermentation increased the availability of protein and also the biochemical changes that occur during fermentation which breaks down proteins by enzymes into simple compounds (Pele et al., 2016), (Saleh et al, 2015). The increased in ash levels in both fermented banjara and soybean awara might be due to bioavailability of minerals Ramadan et al., (2013) reported similar findings. High moisture of both fermented banjara and soybean awara implies that it does not have a long shelf life and cannot be stored for a very long time (Ogbe et al., 2017). The significant decrease exhibited by fermented banjara bean with regard to fat content might be due to dissociation of lipid complexes, Ragab et al., 2012 reported similar findings. And lipid play and important role in diet as important energy source. And increase in fat content of fermented soybean was observed and is consistent with the earlier report of 
Saleh et al., 2015. Low levels of calcium and potassium in the fermented banjara and soybean awara could be as a result of the processing. An increase in essential minerals such as sodium, iron and magnesium in fermented samples could be due to reduction in the antinutritional properties during processing Saleh et al, 2015. Since lactic acid fermentation changes a diet of low iron bioavailability to diet of high iron bioavailability Saleh et al., 2015, reported similar findings. Sodium is needed in the body in small amount to help maintain normal blood pressure and normal function of muscles nerves iron is used in the management of iron deficiency anemia since iron is a vital part of red blood cells that carries and release oxygen (Mches Rodger, 1997). Processing (Soaking, dehulling, fermentation) decreased the levels of anti-nutritional factors in both banjara and soybean awara, this is in accordance with the report of Bintu et al., 2015 who reported a decrease in the antinutritional content of cowpea. The low levels of tannin observed may be as a result of enzymatic activity of the organisms whose hydrolyzing ability is enhanced by fermentation Wakil and Kazeem, 2012). The reduction in phytic acid content of awara from both soybean and banjara awara may be due to hydrolysis of phytate by the enzyme phytase which breaks phytate into lower inositol phosphate which are believed to be activated during the fermentation and germination process Wakil and Kazeem, 2012, reported similar work in assessing the quality of weaning food using cereal and legumes. The reduction in tannin could be attributed as a significant effect of soaking, dehulling and fermentation which significantly decrease the effect of tannin which is similar to the findings of (Pele et al., 2016).

The result for In vitro protein digestibility at 6 hour shows a higher digestibility rate in fermented banjara and soybean and at 1 hour shows that the digestibility of soybean and cowpea protein is low when the only treatment

is heating. But further processing including soaking, sprouting, fermentation, grinding and hot water extraction increase digestibility of soybean and cowpea. Protein also varies with the type of modern soybean and cowpea product. Steaming at $100^{\circ} \mathrm{C}$ inactivates the anti-nutritional factors in non-fermented soybean and cowpea, thus rendering a maximum protein efficiency ratio. Soy milk and cowpea milk should always be boiled for 5 to 10 minute before consumption so that no active haemagglutinins will be present (Loo, 1978). According to Idris and Dabo, 2016, the degree of processing of soybean increases cowpea digestibility.

The result for vitamin content reveals that there was no significant increases or decreases of vitamin content in some samples while there was a significant difference in other samples, this prove the fact that Fermentation does not always result in increased vitamin concentrations since microorganisms that are involved in fermentation process also require vitamin for growth. Some microorganism is well known for producing vitamins, for example, streptococcus thermophilus, others does not influence or even consume vitamins, for example, lactobacilli. Fermentation conditions such as incubation temperature, length of incubation, and medium further impact the vitamin content of fermented food (Bintu et al.,2015).

\section{CONCLUSION}

It can be concluded from this study that fermented banjara and soybean awara had higher nutritional qualities than the non- fermented samples. However, fermented soybean awara which is free of anti-nutritional factors is more suitable of protein and fat as a local cheese. 


\section{RECOMMENDATIONS}

The following recommendations were made for further studies in order to improve the quality and acceptability of awara

- Cost analysis

- Storage stability

- Effect of wet milling and dry milling on the quantity of 'awara'

- Fermentation yield

\section{REFERENCES}

Akem, C.N. (1991). Soybean Disease: Biology, Identification, Control and Management. International Institute of Tropical Agriculture (IITA). Research Guide No., 41 Ibadan.

AOAC (2010). Association of Official and Analytical Chemist. Official Methods of analysis. Washington DC., Vol

II. No. $44,16^{\text {th }}$ Edition pp 22-33

Bintu, B.P., Hajjagana, L., Falmata, A.S., Modu, S. \& Shetima, Y. (2015). Studies on the evaluation of the nutritional quality chemical composition and rheological characteristics of a cereal of fortified with legume as a weaning of food blend, International Journal of Biotechnology and of Food Sci., vol. 3(1) pp, 1 - 9. ISSN 2384 7344. Research paper.

Davies N.T. \& Raid, H. (1979). An evaluation of phytate zinc availability form soya based textured - vegetable protein meat substitutes or meat extenders. British Journal of Nutrition., 41:579.

Desronches, S., J.F., Mauper, L.M., Ausman, A.H., Lichtenstain, G. B. \& Larmarche,V. (2004). Soyprotein favourably affects LDL size independently of isoflthe avones in hypercholesterolemic men and women. Journal of Nutrition., 134: 574-579.

Farah, Z. \& Fischer, A. (2004). Milk and meat from the camel; a handbook in product and processing, pp 29 Zurich, vdfhochschulverag AG.

Fukushima, D. (1981). Soyprotein for Foods Centering Around Soysauce and Tofu. Journal of American Oil Chemistry Society., Pp.58:346.

Ganiyu, O., \& Ekperigin, M.M. (2007). Effects of types of coagulant on the nutritive value and in vitro multienzyme protein digestibility of tofu. Journal of food and Technology., 3: 182-187.

Idris, A., \& Dabo, N.T. (2016). Microbiological and Nutritional analysis of Soybean Cake (awara) and Camel Milk Cheese (Chukwii) Local snacks, vended in Kano Metropolis. UMYU. Journal of Microbiology Research. ISSN: Vol 1(1) pp 7-14.

Koskowski, F.V. \& Mistry, V.V (1997). Cheese and fermented milk foods, third edition, vol1. F. v. kozachoks 
L.L.C, Westport, CT. La Barbera, M. (2012). List of types of cheese [online]. [Accessed 12 July 2015]. Liu, Keshun (1997). Soybean: Chemistry, Technology and Utilization, Springer. Pp. 532.

Loo, T.G. (1978). Small-scale and home processing of soybeans with applications and recipes (communication 64a). Department of Agricultural Research of the Tropical Institute, Amsterdam., pp-59

Mehas, K.Y. \& Rodgers, S.I. (1997). Food Science. The Biochemistry of food and nutrition, Glencoe/ McGrawHill, Peoria. Illinois., U.S.A. 35: 169-171.

Naaz A.S., Yellayi, M.A., Zakrocymski, D., Dunick, D.R., Doege, D.B. Ludatin, W.G., Helferich, H. \& Cooke, P.S. (2003). The soy isofavone genistein decrease adipose desposition in mice. Endocrinol., 144; 3315-3320

Nazim, U.U., Mitra, K., Rahman, A.A., Abdullah,A.T.M. \& Parveen, S. (2013). Evaluation of nutritional quality and microbiological analysis of newly developed soy cheese. International Food Research Journal., 20(6): 3373-3380.

Oladipo, I.C. \& Jadesimi, P.D. (2013). Microbiological analysis and nutritional evaluation of west African soft cheese (wara) produced with different preservatives. American Journal of Food and Nutrition., 3(1): 13-21`.

Pele,G.L., Ogunsua, A.O., Adepeju, A.B., Esan, Y.O., \& Oladit, E.O. (2010). Effect of Processing Methods on the Nutritional and anti-nutritional properties of soybean (glycine max). Africa Journal of Food Science and Technology., Vol 7(1) pp 009-012

Ragab, H.E., Kijora, C., Abdelat, K.F., \& Danor, J. (2010). Effect of traditional processing on the nutritive value of some legume's seeds produced in Sudan. International Journal of Poultry Science., 9:198-204.

Saleh et al. (2015). Effects of fortification of rice with Banjara beans and sesame on chemical composition mineral elements and vitamin contents of a complementary meal. EC nutrition., 1.2: 35 - 40.

Schaeffer, J. (2012). Daring food substituent. The sky's the limit [online available; www.todaysd com/newsarchieve/080112p38.shttm.

Wakil S.M. \& Kazeem, M.O. (2012). Quality assessment of weaning of food produced from fermented cereal legume blend using starter. International of food research journal., 19(4): 1679 - 1685. 